\title{
Women's participation on tourism villages' management in the Dieng Pandawa Tourism awareness group
}

Tuti Widiastuti

Bakrie University, Indonesia, tuti.widiastuti@bakrie.ac.id

Eli Mihardja

Bakrie University, Indonesia

See next page for additional authors

Follow this and additional works at: https://scholarhub.ui.ac.id/ajce

Part of the Social and Behavioral Sciences Commons

\section{Recommended Citation}

Widiastuti, Tuti; Mihardja, Eli; and Agustini, Prima (2019). Women's participation on tourism villages' management in the Dieng Pandawa Tourism awareness group. ASEAN Journal of Community Engagement, 3(1).

Available at: https://doi.org/10.7454/ajce.v3i1.175

Creative Commons License

(c) (i) ()

This work is licensed under a Creative Commons Attribution-Share Alike 4.0 License.

This Research Article is brought to you for free and open access by the Universitas Indonesia at ASEAN Journal of Community Engagement. It has been accepted for inclusion in ASEAN Journal of Community Engagement. 


\title{
Women's participation on tourism villages' management in the Dieng Pandawa Tourism awareness group
}

\author{
Tuti Widiastutia ${ }^{*}$, Eli Mihardjaa, Prima Agustini ${ }^{a}$ \\ a Bakrie University, Indonesia
}

Received: May 28 2019 || Revised: July 9 $9^{\text {th }}, 2019$ || Accepted: July 31'st 2019

\begin{abstract}
Dieng Kulon is a popular tourist visit area that has many tourist attractions. In which there is a program that aims to develop rural communities, namely the tourism village program. Tourism village is a form of integration between attractions, accommodations and supporting facilities that are presented in a structure of community life that is integrated with prevailing procedures and traditions. The research was conducted by using a qualitative descriptive approach by utilizing key informants using field observations and in-depth interviews Kelompok Sadar Wisata (Pokdarwis) or Tourism Awareness Group Dieng Pandawa Pandawa is a group that makes its institution a forum for community consultation and communication in the region of Dieng Kulon Village, Batur Sub district, Banjarnegara Regency which involves women (perpetrators of typical homestay and home food industry managers). The involvement of women in the tourism sector seems to be increasing in all fields of tourism business. For women involvement in the development of capabilities in the tourism group membership provided a satisfaction for them so that they could produce better in the future. Finally through this study is attempting to improve the ability of women to manage homestay in the marketing communication mix.
\end{abstract}

Keywords: women's participation, communication mix, tourism village management, Dieng Pandawa, tourism awareness group

\section{Introduction}

Dieng Kulon is a Dieng Plateau located in two districts, Wonsosobo Regency and Banjarnegara Regency. Dieng Kulon or Dieng Plateau is a popular tourist visit area that has many tourist attractions. Dieng is a mainstay for travelers who are on their holidays to the Central Java area. Dieng has diverse natural wealth and abundant agricultural wealth. A variety of Dieng attractions can tourists find at each step. The cool air, extensive agriculture, beautiful mountains, charming natural lakes, beautiful sunrise to the interesting culture and culinary really attract millions of tourists to visit Dieng Kulon.

Since ancient times Dieng Kulon or Dieng Plateau has become the main destination for traveling. The early history of Dieng has its own meaning, namely from the word Diyang or Dihyang which has the meaning of the dwelling place of the Gods. In addition, Dieng is 
Tuti Widiastuti, Eli Mihardja, Prima Agustini | ASEAN Journal of Community Engagement | Vol. 3, No. 1, 2019

a place that has been sought as a place of human communication with its creators, but not only communication, it needs to be raised here to give birth to archipelago development thinkers in Java. Until the Brahmins who had communicated made another place in the Syailendra dynasty to make a place called the Darmasala area, a few years ago it was used as an example where the building was originally using wood. The time was made for Brahmin dwellings to be used as an administrative, architectural area. Judging from this, there must be a regulating relationship between human communication and the creator.

There is a program that aims to develop rural communities, namely tourism village programs. Tourism village is a form of integration between attractions, accommodation and supporting facilities that are presented in a structure of community life that is integrated with prevailing procedures and traditions (Zakaria \& Suprihardjo, 2014; Rahayu, 2018). The most important thing in community development (including tourism village programs) lies in the realization of the use of all available resources. The tourism village component includes the participation of local communities, the local norm system, local customary systems, and local culture (Prasiasa, 2012).

Male and female population is a supporting force in development, especially related to human resources. Women's population has a role in nation building as a workforce in various sectors, one of which is the tourism sector. The tourism sector is one of the work sectors that require women as their workforce, but women are still difficult to actualize themselves in the life of society, nation and state.

Women are an important resource that should be used well in community development activities, especially in rural communities (Andani, 2017; Dumbraveanu, Light, Young, \& Chapman, 2016; Dunn, 2007; Nakata \& Momsen, 2010). Argyo (2009) revealed that in addition to lack the role of the community in management, the lack of success of community-based tourism is also caused by the lack of roles of women. Indirectly this means that the success of community-based tourism is determined by the role of the community including women. Women as part of the community have the rights and potential to participate in community-based tourism activities (Hidayah, 2007).

The role of women in the field of tourism is conceptually expected to be directly or indirectly a tool for analyzing development and overcoming disparities in economic 
growth (Karmilah, 2013; Kannegieser, 2015; Aziz \& Selamat, 2016). The role of women in the tourism sector can be seen in tourism management. One tourist destination that has a role for women in Dieng Kulon is Tourism Village. Tourism village is a rural area that offers authenticity both in terms of social culture, customs, daily life, traditional architecture, and village spatial structure presented in a form of tourism component integration such as attractions, accommodations and supporting facilities. One of the tourist villages is in Dieng Kulon.

Kelompok Sadar Wisata (Pokdarwis) or Tourism Awareness Group Dieng Pandawa is a group that makes its institution a forum for community consultation and communication. Dieng area is in Dieng Kulon Village, Batur Subdistrict, Banjarnegara Regency. Furthermore, the success of the Pokdarwis is not only able to empower young people and even all levels of society from parents (art and culture actors), farmers, women and mothers (actors who manage homestay and home food industry). Pokdarwis Dieng Pandawa is an example of tourism community empowerment that results in the formation of other Pokdarwis in the Dieng area such as Pokdarwis Karangtengah Village, Pokdarwis Kepakisan Village, Pokdarwis Sembungan Village, Pokdarwis Dieng Wetan Village and Pokdarwis Pekasiran Village and many more so that today Pokdarwis Dieng Pandawa always a study for other villages. In Pokdarwis Dieng Pandawa cannot be separated from the role of women in the management of tourist villages in Pokdarwis Dieng.

Dieng Kulon Tourism Village is unique in the role of its managers. The uniqueness is because various tour packages are mostly managed by women, which is different from other tourism objects, the managers are usually dominated by men. Women have an important role in tourism; this is due to the nature of women who are more thorough and creative than men. These characteristics have the potential for development in the field of tourism.

The role of women when explored more sharply in tourism activities has a more important influence than men, not only due to social and cultural differences, but also based on the creative power possessed by women. The creativity possessed by women in Dieng Kulon Tourism Village is caused by the existence of a strategic role that is borne by women in management in tourism activities, especially homestays. The creativity of work carried out by women will influence the handling of community income problems in the Dieng Kulon Tourism Village. 
Scheyvens (2000) states that there are four dimensions that needs to be discussed to determine whether women have been empowered in tourism activities, in developing countries including Indonesia. The four dimensions include empowerment seen from an economic, social, psychological and political point of view (Scheyvens, 2000). Even though this is a conversation regarding the empowerment of local communities towards tourism activities is more focused on economic issues, in reality tourism development is a multidimensional activity, not just an economic problem.

Women are indeed an inseparable part of tourism activities even though for the Indonesian context the role of women in tourism activities still revolves around work related to domestic activities, such as cooking (Satyawan \& Utami, 2000). While the absorption of labor in other fields that require special skills is still dominated by men. Therefore, this research activity was held to determine whether tourism activities which one of the objectives is to improve the welfare of local communities socially, economically and culturally in the Dieng.

Women play an important role in fulfilling the family's economy, but their role in the economic field is often overlooked and still not taken into account. This can be proven by the data collection of women in the workforce which is only done in the formal sector, while the workforce in the domestic and informal sectors has not been considered an activity productive so that women working in this sector do not count as labor force (Karmilah, 2013). In fact, many women play an important role in homestay businesses in Dieng from 9 homestays in 2006 to 140 homestays in 2018. Type this business is in great demand by women's groups because it can support the family economy, increase self-actuality and open up opportunities for improving the quality of family welfare.

The main problems in women's economic empowerment are inseparable from the low skills of women in marketing communication (Kannegieser, 2015). This is indicated to be a factor in the underdevelopment of women in economic development, namely the limited insight, ability, and access to communication technology, which results in weak knowledge of business management. In addition, the homestay business initiated by women is not legal or informal so it is difficult to develop.

The problem of labor seems not too big to be felt by female homestay entrepreneurs. This is related to the characteristics of the products produced are relatively simple and 
do not need high expertise. The solution is to develop business creativity. This relationship is developed through the patterns of marketing communication mix strategies that are informative, friendly, conditional, and business objectives to create a conducive business climate in the fields of product quality, promotion, marketing, mentoring and coaching. In addition, a partnership pattern for relations between actors is also needed based on business ties that mutually support each other based on the principle of equality and togetherness.

In addition, the main problem experienced is the lack of understanding and innovation in marketing management, causing the product not to be marketed properly. These problems will certainly have an impact on the productivity and use of homestays. The right solution to the main problem, namely marketing management in this era of globalization can actually be solved by online marketing communication either through websites, online applications, and social media such as Facebook, Instagram, Twitter, and YouTube. The results of this study attempt to improve the ability of female homestay managers in the marketing communication mix.

Referring to this phenomenon, this research activity was designed with the main intention to provide an overview of the role of women in the tourism sector, especially regarding empowerment in the development of tourism villages. Women working in the tourism sector have proven to be improving so well that in order to support this research a re-assessment of women's involvement in the management of tourist villages is needed. With the above phenomenon, this research will focus on two things; (1) Form the productive role of women in managing homestays in the Dieng Kulon tourist village area; (2) women's contribution to improving the performance of tourism awareness groups.

\section{Methods}

The research was conducted within 6 months using a qualitative descriptive approach by utilizing key informants using field observations and in-depth interviews. Qualitative descriptive research is a preliminary study that is described and discussed with theories or concepts and is integrated from the data of views and opinions of key people involved in the tourism sector in the Dieng region. The approach used in this study is a 
Tuti Widiastuti, Eli Mihardja, Prima Agustini | ASEAN Journal of Community Engagement | Vol. 3, No. 1, 2019

participatory approach, with the main method directed at women's activities in managing homestays.

The research sample was taken purposively in determining the actors involved in tourism activities in the tourist village area of Dieng. The data collection techniques are used in implementing community service in the field are as follows: 1) field observation, and 2) interviews and focus group discussion. In the research the focus of the observations was on the role of women's creativity in their role in tourism activities in Dieng Kulon Tourism Village, because the tourism activities had an important role for each woman and her activities. The results of this study attempt to improve the ability of female homestay managers in the marketing communication mix. The data in this study were taken from women who played an active manage homestay in tourism in Dieng Kulon Tourism Village. Analysis carried out on the role of women and their influence in tourism activities to enhance women's creativity in tourism activities and community income from tourism activities in Dieng Kulon.

Interviews is conducted to obtain information that was not directly found in the field. In-depth interviews were conducted with female homestay owner, the committee Dieng Pandawa, Committee Dieng Culture Festival (DCF), Merchant Association, Community Leaders, Adat Stakeholders, Youth Figures, Office of Tourism and Culture (Disparbud) Wonosobo, Regional Development Planning Agency (Bappeda) Wonosobo, and Communication Services and Informatics Wonosobo. 3) Document studies conducted by looking for literature relating to all ongoing field practice activities.

The focus group discussion $(n=20)$ method is conducted with participants from official and administrator of Tourism Awareness Groups (Pokdarwis). The theme of the discussion consisting of a series of semi-structured and open questions was developed to be used in this study. Questions related to demographic profile, experience, and challenges in managing tourism villages in Dieng.

Both types of data are combined to get a clear picture of the problems being studied so that a clear picture of how the women's empowerment in the tourism sector in the Dieng tourism village is obtained. Analysis was carried out on data collected from a series of interview observations conducted. The analysis requires using a specific theme, with the results obtained presented in terms of themes discussed including the role of female homestay owners and the role of women in the development of tourism villages. 


\section{Results and Discussion}

The process of becoming a tourist village requires the collaboration and participation of the entire community. When it comes to the management of tourist villages, Pokdarwis Dieng Pandawa creates a forum for community consultation and communication in the Dieng area, which is in Dieng Kulon Village, Batur Subdistrict, Banjarnegara Regency. Pokdarwis empowers all levels of society from young people to their parents (as art and culture actors) and farmers, women, and mothers (as actors who manage the home stay and home food industries). Pokdarwis Dieng Pandawa is an example of a tourism community empowerment modeled after other successful Pokdarwis-Pokdarwis in the Dieng area, such as Pokdarwis Karangtengah Village, Pokdarwis Kepakisan Village, Pokdarwis Sembungan Village, Pokdarwis Dieng Wetan Village, and Pokdarwis Pekasiran Village. Today Pokdarwis Dieng Pandawa can serve as a model for other villages to study. Pokdarwis Dieng Pandawa recognizes that women, who are responsible for homestays and typical home food production, play an essential role in the management of tourist villages. The results were based on discussions conducted by Ms. Tina, who is the homestay working group leader. Ms. Tina is not a native of Dieng, but a migrant from Malang.

\subsection{Business Groups of Pokdarwis}

Pokdarwis Dieng Pandawa now consists of all tourism stakeholders and has no become a Dieng Tourism Cluster Rembug Forum and is voluntarily in accordance with Pokdarwis Dieng. At present the more than 300 personnel are spread across eight business groups (Pokja) or Pokdarwis Section Dieng Pandawa:

1. Typical Food Industry Home Industry Working Group

There are several typical food industries developed and managed by the Dieng Kulon Tourism Village community, such as the Carica Syrup Industry, Purwaceng Drink Industry, Potato Chips Industry, and others. These industries have very good economic prospects. Infact, some of these products have been exhibited in the title of National Community Empowerment Work at JCC Jakarta.

2. Craft Working Group

There are several SMEs under the guidance of Pokdarwis that have become their own Pokja and been facilitated by training from the Central Java Province and PNPM 
Tourism Culture and Tourism Office: 1) Kayu Dewa Batik, wooden batik is one of Dieng's unique handicrafts, which has a unique, namely batik media using native Dieng wood, such as Cemeti, Pringgondani, Tengsek, and others. 2) Screen Printing Shirt Dieng is an SME that produces souvenirs in the form of t-shirts that have words and images that identify themselves as Dieng tourism objects. 3) Miniature temple Dieng is dedicated to miniature temples made by the people of Dieng, using two kinds of materials, namely Gibsum and wood. The miniature is modeled after temples in Dieng.

3. The Home Stay Working Group

The Home Stay Working Group is a very significant group since tourists who stay for a certain time depend on home stays. Currently there are 62 houses in Dieng Kulon that belong to the homestay working group

4. Art and Culture Working Group

This working group consists of artists and cultural figures and is devoted to developing the tourism industry based on the culture of local wisdom. Of course, this working group organizes special events and attractions to develop tourism in the Dieng region.

5. Tour Guide Working Group

The membership of this working group has many young people who are engaged as local guides and outbound tourism.

6. Working Group on Agro Tourism

This working group consists of farmers who have facilities to host tourists and introduce them to the region's agricultural activities.

7. Security Working Group

This working group consists of youth and community members engaged in maintaining security and order.

8. Marketing Working Group

This working group provides tourism-oriented public relations, promotion, and marketing. It also raises awareness of the members or Pokdarwis Dieng Pandawa forum members. It communicates with printed and other media, cooperates with tourism bureaus, manages several web sites, and actively participates in exhibitions. 


\subsection{Women's Participation in Tourism Village Management}

The development of homestays in the Dieng Kulon Tourism Village area with women's roles is very strong. This can be seen from the large level of women's participation in homestay management. In the study it was found that there was a substantial portion of women in managing homestays. This is certainly interesting considering that homestays are usually managed by men who understand the management of a tourism accommodation (Nadzirah, 2015).

Based on the results of the analysis that has been done previously, it can be concluded that the activity everyday people are farming which is a characteristic Dieng has the potential to be developed become an agro-tourism-based village area who has other tourist attractions, providing a route tourist trips that surround the tourist village are which shows the daily activities of the Dieng community, providing special means of transportation for towards the tourist village area to make it easier tourists visiting the tourist village area and providing supporting facilities and supporting activities tour.

The establishment of homestays since 2006, at present there are only about 9 homestays. Ms. Tina is the 5th generation leader, at that time 76 now have grown to 140 who have joined the homestay community.

Paguyuban homestay Dieng Pandawa outside the community association is around 40-50s. When Mrs. Tina became chairman, there was no training from the government, because the government considered the homestay to be independent. On the other hand the development of the homestay is also inseparable from the role of tour guide. Mrs. Tina and the other administrators made their own study from the community. This homestay has also worked with several online ordering applications. Among them are Traveloka, seconds, blibli.com. Besides that the association also conducts English language courses because tourists are not only in the country but also abroad. Many are members of the community and the majority of mothers are due to community empowerment.

Here, it shows that women have a role as the main actors in the availability of these facilities; on the other hand, they manage the homestay community as well as women. Because women are believed to be able to manage facilities such as preparing rooms, preparing food for tourists and in terms of cleanliness and tidiness so that not a few homestays in Dieng get awards. And on the other hand the role of women in food and 
Tuti Widiastuti, Eli Mihardja, Prima Agustini | ASEAN Journal of Community Engagement | Vol. 3, No. 1, 2019

beverage services shows that the role of women is shopping for food, processing it into cuisine to serving tourists. Because when we stay at the homestay we get breakfast. The management of homestays is also a member of the community, this association serves to share with each other and deliver information from the service and conduct training. The role of women in managing the tourism village in Dieng Pandawa is quite large. One of them is a homestay association. Because in them the high positions occupied by women can be seen from a long time ago the position of the head of the community of homestays by women (Subekti, 2017).

The participation of women in this area is indeed a lot of help activities, tourism aspects that concern women in this Dieng area are food processing such as making karika and purwaceng, as well as cultivating potatoes and then distributing to outside the city such as the Tasik market, to Purwokerto since long ago Dieng was famous for potatoes. In the 1980s, Bandung people came in for potato cultivation. The economy developed rapidly in the early 90s, and potatoes were golden plants and became expensive vegetables, and the surrounding community was complacent. One kilogram of potatoes can buy potatoes like buying $4 \mathrm{~kg}$ of rice. One time harvest can be up to $20 \mathrm{Kg}$ $40 \mathrm{Kg}$. It can be said that the role of women is very dominant in the management of agricultural activities. Women are involved in agriculture because they make it a livelihood to help the family's economy. Because this woman only works with her husband does not employ others.

The participation of women in homestay shows that women have a role as the main actors in the availability of such facilities such as preparing rooms to be used by tourists, provide food for tourists, and more (Aziz \& Selamat, 2016; Deen, Harilal, \& Achu, 2016). Women involved in homestay facilities are women his home was designated as a homestay because it fulfilled the predetermined basic requirements of having one empty room and a bathroom inside the house. Regarding to the basic requirements, actually the interest of the people so that their homes are designated as homestays is quite a lot. Because their homes do not meet the requirements so they cannot be involved in this facility.

Unfortunately, people feel troubled in terms of communication because the community is not fluent in English. For fee to homestay, there are no differentiated rates between local tourists and foreign tourists. There should be a difference in the rates charged as in other tourism objects. The accommodation offered is still privately owned, 
namely from the residents of Dieng. If tourists want to take a tour package then they can contact the manager and manager to facilitate the accommodation.

For women who are interested in being involved but not having ability must undergo coaching first, but for now there are still a few women who play a role in the tourist organization. In every activity carried out sometimes there are always obstacles that are experienced. Likewise with women in playing a role in tourism activities in Dieng where the constraints of women in their role in general are lack of skilled and trained human resources.

In the area of Dieng Kulon Tourism Village women not only have internal functions but also external functions that have implications for improving family welfare. Empowerment in a gender perspective is development for women in terms of independence and internal strength, and emphasizes the equality of men and women (Andani, 2017). In the sense that there is recognition of the meaning of productivity in women's activities even though it is carried out in the household as long as it can increase household income, develop women's organizations, increase awareness, and educate the community as an important condition for social change for women's groups.

The development of homestays in the Dieng Kulon Tourism Village area with women's roles is very strong. This can be seen from the large level of women's participation in homestay management. In the study it was found that there was a substantial portion of women in managing homestays. This is certainly interesting considering that homestays are usually managed by men who understand the management of a tourism accommodation (Nadzirah, 2015).

Based on the results of the analysis that has been done previously, it can be concluded that farming, which is characteristic of Dieng tradition and regional identity, could be developed into an agro-tourism-based village area with other tourist attractions, providing a tourism route that surrounds the village area that displays the daily activities of the Dieng community. Special means of transportation based in the tourist village area would make it easier for tourists visiting the village area and could integrate with supporting facilities and tourism activities. 
Tuti Widiastuti, Eli Mihardja, Prima Agustini | ASEAN Journal of Community Engagement | Vol. 3, No. 1, 2019

\subsection{Marketing Communication Ability Women Managing Homestay in Dieng Kulon}

\section{Tourism Village}

The involvement of women in the tourism sector seems to be increasing in all fields of tourism business. Although it seems still limited, this research data shows that among tourism objects that can be identified in the tourist area of Dieng, most have involved women in various sectors. This study looks at the involvement of women in tourism activities, from two sides, they are, who sit as owner and those who are directly involved in tourism activities such as homestay.

There is an assumption that women are emotional, so women are not right as managers. However, from the aspect of negotiating women, the situation is higher than that of men. From the results of the study of the tourism business negotiation process was completed by women was carried out directly by men. The ability of public communication and beauty maturity are the main reasons. They are often actively involved and participate in coordinating tourism activities and providing assistance both morally and materially. They are also active in carrying out business activities to foreign countries and several places in Indonesia and have a fairly good network including consumers.

Besides that their ability to organize to develop their business can be said to be quite good so that slowly but surely they are able to develop their business. Women's income in tourism on average is only considered as additional income in the family. In other words it can be said that tourism provides economic benefits for local residents. Scheyvens (2000) states that usually these women are not included in formal employment and this is also found in this study.

Based on the employment status of women workers are more involved in the types of activities including the informal sector, while men in the formal sector. All informants are domiciled as ordinary workers not with a certain position, even though there is one that has a dual function, namely as a worker in the managerial aspects as well as a seller because it is women who are responsible when dealing with customers.

With tourism, women are expected to be more actively involved not only as workers but their role and status increase. In terms of formal employment experience in other regions shows that women are usually not so interested that they often cause problems around the place. Based on job titles, female workers experience marginalization as a 
feminization (Deen et al., 2016). This can be seen from the concentration of female workers into positions that seem to be the work of women, such as marketer, traders, and domestic or household jobs.

Working in the tourism sector makes women get additional knowledge indirectly, such as the ability to communicate with foreigners, management skills increase. As these abilities increase they are socially having a better bargaining position. Working they feel they have added value in the community. This makes them feel more valued than just an ordinary housewife.

Women involved in the homestay tourism activities are included in the lower middle class and their involvement does not seem to be particularly evident for tourism development. This is caused by several things, for example, they do not have sufficient access to play an active role in tourism activities or because of their busy helping the family economy they do not have enough free time to actively participate. Although some have stated that so far they have gained more learning opportunities, so that their income is increasing along with their increased skills in managing homestay or room services. In general, they argue that women's involvement in tourism is still very limited for various reasons, as mentioned above, such as socio-cultural, limited ability and limited time they have.

They feel working with a situation that is now quite good, compared to if they do not work or do not earn. This is one of the problems faced by women in general, who consider working whatever their income is better than not working at all. With the involvement in tourism, informants also believe that the community is more appreciative so that they are more participate in social activities in their environment such as Pokdarwis and have more confidence because they feel they are superior compared to those who do not work. Joinin in groups, the function of social empowerment can increase. A sense of unity and unity because they are bound in the same activities will provide higher social dynamics which in turn each individual feels included in economic activities that produce. For women involvement in the development of capabilities in the tourism group membership provided a satisfaction for them so that they could produce better in the future.

Providing assistance in the form of marketing communication mix training, tourism workers can improve their ability in the field of homestay management to be used as 
Tuti Widiastuti, Eli Mihardja, Prima Agustini | ASEAN Journal of Community Engagement | Vol. 3, No. 1, 2019

tourism development in the area of Dieng tourism village. Furthermore, there must be some parties who help accelerate their ability to be more advanced, for example the government, non-governmental organizations and private parties engaged in tourism.

Women play an important role in fulfilling the family's economy, but their role in the economic field is often overlooked and still not considered. This can be proven by the data collection of women in the workforce which is only done in the formal sector, while the workforce in the domestic and informal sectors has not been considered an activity productive so that women working in this sector do not count as labor force (Karmilah, 2013). In fact, many women play an important role in homestay businesses. Type this business is in great demand by women's groups because it can support the family economy, increase self-actuality and open opportunities for improving the quality of family welfare.

The main problems in women's economic empowerment are inseparable from the low skills of women in marketing communication (Kannegieser, 2015). This is indicated to be a factor in the underdevelopment of women in economic development, namely the limited insight, ability, and access to communication technology, which results in weak knowledge of business management. In addition, the homestay business initiated by women is not legal or informal, so it is difficult to develop.

The problem of labor seems not too big to be felt by female homestay entrepreneurs. This is related to the characteristics of the products produced are relatively simple and do not need high expertise. The solution is to develop business creativity. This relationship is developed through the patterns of marketing communication mix strategies that are informative, friendly, conditional, and business objectives to create a conducive business climate in the fields of product quality, promotion, marketing, mentoring and coaching. In addition, a partnership pattern for relations between actors is also needed based on business ties that mutually support each other based on the principle of equality and togetherness.

In addition, the main problem experienced is the lack of understanding and innovation in marketing management, causing the product not to be marketed properly. These problems will certainly have an impact on the productivity and use of homestays. The right solution to the main problem, namely marketing management in this era of globalization can be solved by online marketing communication either through 
websites, online applications, and social media such as Facebook, Instagram, Twitter, and YouTube.

Pokdarwis Dieng Pandawa provides a forum for community consultation and communication in the Dieng area in Dieng Kulon Village, Batur District, Banjarnegara Regency. It is the first Pokdarwis form in the Dieng area of Banjarnegara, Wonosobo, and Batang. In it there are women and mothers (actors who manage the home stay and home industries). The results show that the role of women in managing tourism villages in Pokdarwis Dieng Pandawa is very important, particularly in managing the homestay community and agricultural activities. Because the management of homestays is very important in a tourist village, the number of tourists who come to Dieng offers economic opportunity to the original Dieng residents who can provide the facilities needed by tourists, such as homestays. The visitors Dieng give women work opportunities, which help them to meet their family's economic needs.

\section{Conclusion}

The tourism sector has been able to create employment opportunities through various types of businesses related to tourism that can be utilized by both male and female workers women. Primarily in the Dieng Kulon Tourism Village area, the development of homestays has provided space for women to improve family welfare including reducing the impact of marginalization of discrimination and subordination reflected in the wage or salary gap. The management of homestay in this tourist area provides real evidence that the potential of women as part of supporting the development of the tourism sector is very large.

The presence of women in managing homestay makes this residence not only as an amenity or accommodation, but also as a tourist attraction. The homestay has a cultural appeal that also allows the interaction of tourists with residents. While as amenities, women play a role by making the homestay a place a healthy, clean and safe stay for the community as well as tourists, with international standard management.

After obtaining descriptive data generated from the supporting factors of women's roles in tourism village management, an analysis involving the participants was carried out. Consensus was formed among all participants regarding the supporting factors for developing tourism village areas in Dieng. Women in the village agreed that they need 
Tuti Widiastuti, Eli Mihardja, Prima Agustini | ASEAN Journal of Community Engagement | Vol. 3, No. 1, 2019

media promotion to identify the tourist village area in Dieng to potential visitors. Having women from the local community manage tourism is necessary so that they play an active role in the development of tourist village areas and receive various necessary trainings. Government policy is taking its own role in controlling the development of tourist village areas in Dieng seriously.

\section{Acknowledgments}

This study is funded and supported by Bakrie University through Community Services Institution project number 132/SPK/LPkM-UB/IX/2018.

\section{References}

Andani, F. (2017). Peran Perempuan dalam Kegiatan Pariwisata di Kampung Wisata Tebing Tinggi Okura Kota Pekanbaru. JOM FISIP, 4(2), 1-11.

Argyo, D. (2009). Pembangunan Pariwisata Berbasis Masyarakat. Surakarta: Sebelas Maret University Press.

Aziz, F. S. H., \& Selamat, N. H. (2016). Performing Gender and Rural Tourism: An Analysis of Homestay's Operators in Penang Island. 3rd Kanita Postgraduate International Conference on Gender Studies, 69-77.

Deen, A., Harilal, V., \& Achu, F. N. (2016). Women in Tourism: Experiences and Challenges Faced by Owners of small Accomodation Establisments. African Journal of Hospitability, Tourism and Leisure, 1-15.

Dumbraveanu, D., Light, D., Young, C., \& Chapman, A. (2016). Exploring Women's Employment in Tourism under State-Socialism: Experiences of Tourism Work in Socialist Romania. Tourist Studies, 16(2), 151-169. https://doi.org/10.1177/1468797615594747

Dunn, S. (2007). Toward Empowerment: Women and Community-Based Tourism in Thailand. Oregon: University of Oregon.

Hidayah, N. I. (2007). Pemberdayaan Masyarakat dalam Pengembangan Desa Wisata Jatimulyo, Girimulyo, Kulon Progo, Daerah Istimewa Yogyakarta. Yogyakarta: Jurusan Ilmu Administrasi Negara, Fakultas Ilmu Sosial, Universitas Negeri Yogyakarta.

Kannegieser, I. (2015). A Home in the Hills: Examining the Socioeconomic Benefits of 
Homestay Tourism on Rural Women and Their Communities in the Darjeeling District. Retrieved from https://digitalcollections.sit.edu/isp_collection/2205

Karmilah, M. (2013). Peran Ganda Perempuan di Lingkungan Pariwisata Bandungan, Jawa Tengah. Jurnal Palastren, 6(1), 129-158.

Nadzirah, I. (2015). Women Empowerment in Organizing Homestay Program Case Study: Homestay Sinaran Baru, Senai, Johor. Johor: Universiti Teknologi Malaysia.

Nakata, M., \& Momsen, J. D. (2010). Gender and Tourism: Gender, Age and Mountain Tourism in Japan. Geografia Malaysian Journal of Society and Spac, 6(2), 63-71.

Prasiasa, P. 0. (2012). Destinasi Pariwisata, Berbasis Masyarakat. Jakarta: Salemba Empat.

Rahayu, A. T. (2018). Gambaran Keberdayaan Perempuan di Desa Wisata Pentingsari Berdasarkan Resident Empowerment through Tourism Scale (RETS). Gadjah Mada Journal of Tourism Studies, 1-11.

Satyawan, A., \& Utami, T. (2000). Pengembangan Pariwisata dan Pengaruhnya terhadap Penyerapan tenaga kerja Wanita: Studi di kepulauan Karimun Jawa. Jurnal Cakra Wisata, 1-13.

Scheyvens, R. (2000). Promoting Women's empowerment through Involment in Ecotourism: Experiences from the Third World. Journal of Sustainable Tourism, (232-249).

Subekti, A. I. (2017). Peran Perempuan dalam pariwisata di desa Wisata Wukirsari kecamatan Imogiri Kabupaten Bantul. Yogyakarta: Universitas Negeri Yogyakarta.

Zakaria, F., \& Suprihardjo, R. D. (2014). Konsep Pengembangan Kawasan Desa Wisata di Desa bandungan Kecamatan Pakong Kabupaten Pamekasan. Jurnal Teknik Pomits, C-245-249. 